\title{
PENGARUH MODEL PEMBELAJARAN INKUIRI TERSTRUKTUR DENGAN PENDEKATAN SAINTIFIK TERHADAP KEMAMPUAN BERPIKIR KRITIS DAN HASIL BELAJAR FISIKA SISWA
}

\author{
Lia Saptini Handriani' ${ }^{1}$, Ahmad Harjono ${ }^{2}$, Aris Doyan² \\ ${ }^{1)}$ Program Studi Pendidika Fisika \\ 2) Program Studi Pendidika Fisika FKIP \\ FKIP Universitas Mataram \\ Mataram, Indonesia \\ Email: Liasaptinihandriani@gmail.com
}

\begin{abstract}
This study aims to determine the effect of structured inquiry learning model with scientific approach on student's critical thinking skills and physics learning outcomes of class X in SMAN 1 Gerung in academic year 2014/2015. The study uses a quasi experiment with design untreated control group design with pretest and posttest. The sample was selected by clauster random sampling and obtained class X-3 as the experiment class using structured inquiry learning model with scientific approach and class X-6 as the control class using expository learning model. Data post-test were tested for normality, homogeneity, and hypothesis test. Hypothesis test using t-test polled variance with $5 \%$ of significance level. The results of the study were obtained: (1) there was the effect of structured inquiry learning model with scientific approach on student's critical thinking skills $\left(t_{\text {count }}=5.78>t_{\text {table }}=1.9983\right)$ and (2) there was the effect of structured inquiry learning model with scientific approach on student's physics learning outcomes $\left(t_{\text {count }}=4.39>t_{\text {table }}=\right.$ 1.9983). This indicates that the structured inquiry learning model with scientific approach is better than the expository learning model. Expected to do further research on structured inquiry learning model with scientific approach that measure the other of higher order thinking skills.
\end{abstract}

Keywords: structured inquiry learning model, scientific approach, critical thinking skills, and physics learning outcomes.

\section{Pendahuluan}

Pada hakikatnya setiap manusia membutuhkan pendidikan, karena pendidikan itu sendiri merupakan salah satu kunci kehidupan. Dengan adanya pendidikan yang dimiliki oleh seseorang maka kehidupannya menjadi lebih baik dan lebih terarah. Tujuan pendidikan itu sendiri adalah untuk menciptakan seseorang yang berkualitas dan berkarakter, sehingga memiliki pandangan yang luas ke depan guna mencapai cita-cita yang diharapkan dan mampu beradaptasi secara cepat dan tepat terhadap perubahan kondisi lingkungan kehidupan terutama adanya perubahan zaman yang berkembang begitu pesat.

Kualitas pendidikan di Indonesia saat ini sangatlah memprihatinkan. Hal ini dapat terlihat pada mutu pendidikan Indonesia yang begitu rendah jika dibandingkan dengan negara-negara tetangga seperti Malaysia, Singapura, Brunai Darussalam, dan Thailand. Hasil riset yang dilakukan oleh UNDP (United Nations Development Programme) terhadap Human Development Index (HDI) yang dirilis pada tahun 2010, Indonesia menduduki peringkat ke-108 dari 169 negara [1]. Oleh karena itu, diperlukan upaya meningkatkan mutu pendidikan di Indonesia.
Mutu pendidikan salah satunya ditentukan di dalam kelas melalui proses pembelajaran, khususnya dalam penelitian ini adalah proses pembelajaran fisika.

Fisika merupakan salah satu bagian dari ilmu pengetahuan alam (IPA). Pada hakikatnya IPA merupakan suatu produk (a body of knowledge), proses (a way of investigating), dan sikap (a way of thinking). Jadi, dapat diambil persepsi bahwa hakikat fisika sama dengan hakikat IPA [2]. Berdasarkan hakikat fisika ini tersirat jelas bahwa yang diinginkan dalam pembelajaran fisika adalah siswa dituntut untuk melakukan suatu kegiatan ilmiah untuk menemukan pengetahuan dan memiliki sikap ilmiah.

Hasil observasi peneliti melalui wawancara dengan salah seorang guru fisika dan beberapa siswa SMAN 1 Gerung menunjukkan bahwa proses pembelajaran yang berlangsung masih menggunakan proses pembelajaran yang bersifat teacher-centered (berpusat pada guru). Pada pembelajaran teachercentered ini siswa cendrung pasif dan mendengarkan penjelasan guru, sehingga pengetahuan siswa berasal dari guru. Proses pembelajaran seperti ini tidak memberikan akses bagi siswa untuk berkembang secara mandiri dalam menemukan sendiri pengetahuannya. Sehingga akan berdampak pada 
kemampuan berpikir tingkat tinggi siswa terutama berpikir kritis siswa yang tidak pernah dilatih. Selain itu, proses pembelajaran yang bersifat teachercentered juga menyebabkan siswa kurang aktif dalam pembelajaran dan berpengaruh terhadap hasil belajar fisika siswa yang rendah.

Berdasarkan persoalan yang telah dipaparkan, peneliti menawarkan sebuah model pembelajaran yang dapat melibatkan siswa aktif dalam proses pembelajaran dan dapat melatih kemampuan berpikir kritis siswa, sehingga diharapkan pada akhirnya dapat meningkatkan hasil belajar fisika siswa, yaitu dengan menggunakan model pembelajaran inkuiri terstruktur (MPIT) dengan pendekatan saintifik. MPIT merupakan kegiatan inkuiri dimana pertanyaan dan prosedur masih ditentukan oleh guru, akan tetapi siswa menghasilkan suatu penjelasan yang didukung oleh bukti-bukti yang telah dikumpulkan [3]. MPIT ini menjadi awal untuk mengembangkan kemampuan siswa untuk berinkuiri sebelum ke jenjang inkuiri tertinggi yaitu inkuiri terbuka.

MPIT berlandasan pada penemuan pengetahuan oleh siswa itu sendiri yang ditempuh melalui berbagai kegiatan ilmiah yang disebut sebagai pendekatan saintifik. Menurut [4] pembelajaran dengan pendekatan saintifik merupakan pembelajaran yang lebih menekankan pada pembelajaran inkuiri, yang memiliki relevansi dengan hakikat sains, yang bukan sekedar kumpulan fakta dan prinsip tetapi mencakup cara-cara bagaimana memperoleh fakta dan prinsip tersebut beserta sikap saintis dalam melakukannya. MPIT dengan pendekatan saintifik diharapkan dapat mengubah proses pembelajaran dari teacher-centred menuju student-centered (berpusat pada siswa). Ketika proses pembelajaran berpusat pada siswa, maka siswa akan dituntut untuk berpikir lebih banyak dalam menyelesaikan persoalan-persoalan yang diberikan oleh guru. Sehingga MPIT dengan pendekatan saintifik ini dapat dijadikan sebagai wahana untuk melatih kemampuan berpikir kritis siswa. Ketika siswa memiliki kemampuan berpikir kritis yang tinggi, maka berdampak pula pada hasil belajar yang tinggi.

Penelitian yang telah dilakukan mengenai MPIT adalah penelitian oleh [5] dan [6] menunjukkan bahwa hasil belajar dengan MPIT lebih baik dibandingkan dengan model pembelajaran konvensional.

\section{TinjauAn PUSTAKa}

\section{A. Model Pembelajaran Inkuiri Terstruktur dengan Pendekatan Saintifik}

National Science Education Standards [7] mendefisnisikan inkuiri sebagai suatu aktivitas yang beragam yang melibatkan kegiatan observasi, mengajukan pertanyaan yang relevan, mengevaluasi buku dan sumber informasi yang lainnya secara kritis, merencanakan investigasi, mereview apa yang telah diketahui, melaksanakan percobaan atau eksperimen dengan menggunaaan alat untuk mengumpulkan data, menganalisis dan menginterpretasi data, serta membuat prediksi, dan mengkomunikasikan hasilnya.

Model pembelajaran inkuiri (MPI) dipandang sebagai suatu proses dimana siswa terlibat aktif dalam pembelajaran, merumuskan pertanyaan, menginvestigasi secara luas, dan kemudian membangun pemahaman baru, pengertian dan pengetahuan. Pengetahuan tersebut merupakan suatu hal yang baru bagi siswa dan mungkin dapat digunakan untuk menjawab sebuah pertanyaan, untuk mengembangkan solusi permasalahan atau untuk menguatkan suatu keadaan atau pendapat [8].

MPI memiliki tingkatan berdasarkan kompleksitas dalam penerapannya. [9] Mengelompokkan MPI menjadi empat tingkatan, yaitu inkuiri terstruktur (structured inquiry), inkuiri terbimbing (guided inquiry), inkuiri terbuka (open inquiry), dan siklus belajar (learning cycle). Penjelasannya sebagai berikut: (1) inkuiri terstruktur, pada kegiatan pembelajaran guru menyediakan rumusan masalah penyelidikan, bahan, dan prosedur, sedangkan hasilnya dicari oleh siswa sendiri; (2) inkuiri terbimbing, pada kegiatan pembelajaran guru hanya menyediakan bahan dan rumusan masalah penyelidikan, dan siswa merancang prosedur penyelidikan untuk mencari jawaban permasalahan; (3) inkuiri terbuka, pada inkuiri ini siswa terlibat dalam merumuskan masalah yang diteliti. Inkuiri ini mirip seperti cara kerjanya para peneliti; (4) siklus belajar, pembelajaran dengan tahap yang sudah diatur sedemikian rupa sehingga siswa ikut berperan aktif dalam proses pembelajaran. Siklus belajar menekankan siswa untuk menemukan konsep baru, kemudian guru memberi jawaban formal nama konsep tersebut, dan siswa mengaplikasikan konsep tersebut dalam konteks yang berbeda.

Pada penelitian ini menggunakan salah satu tingkatan inkuiri oleh [9] yaitu model pembelajaran inkuiri terstruktur (MPIT). MPIT merupakan kegiatan inkuiri dimana guru menentukan topik, pertanyaan, bahan, dan prosedur sedangkan analisis hasil dan kesimpulan dilakukan oleh siswa [10]. 
Berdasarkan uraian di atas MPIT adalah suatu model pembelajaran yang melibatkan siswa aktif dalam proses penemuan pengetahuan melalui kegiatan eksperimen dengan panduan LKS yang telah disediakan rumusan masalah, alat dan bahan penelitian, serta prosedur penelitian, sedangkan tugas siswa menyimpulkan hasil penelitian berdasarkan serangkaian tahapan penelitian yang dimulai dari tahap penetapan masalah, merumuskan hipotesis, melaksanakan penelitian, mengolah dan menganalisis data, dan menguji hipotesis.

Kegiatan MPIT tidak terlepas dari kegiatan imliah, karena model ini berlandasan pada penemuan yang ditempuh melalui serangkaian kegiatan ilmiah. Kegiatan ilmiah inilah yang disebut sebagai pendekatan saintifik. Menurut [11] pembelajaran melalui pendekatan saintifik adalah proses pembelajaran yang dirancang sedemikian rupa agar peserta didik secara aktif mengkonstruksi konsep, hukum atau prinsip melalui tahapan-tahapan mengamati (untuk mengidentifikasi atau menemukan masalah), merumuskan masalah, mengajukan atau merumuskan hipotesis, mengumpulkan data dengan berbagai teknik, menganalisis data, menarik kesimpulan dan mengomunikasikan konsep, hukum atau prinsip yang ditemukan.

Berdasarkan uraian di atas, peneliti mendefinisikan MPIT dengan pendekatan saintifik adalah suatu model pembelajaran yang melibatkan siswa aktif dalam proses penemuan pengetahuan melalui kegiatan eksperimen dengan panduan LKS yang telah disediakan rumusan masalah, alat dan bahan penelitian, serta prosedur penelitian, sedangkan tugas siswa menyimpulkan hasil penelitian berdasarkan serangkaian aktivitas siswa dalam memecahkan masalah melalui tahapan mengamati, menanya, menalar, mencoba, menyimpulkan, dan mengkomunikasikan.

\section{B. Berpikir Kritis}

Berpikir kritis dimulai dari salah seorang kontributor terkenal yang bernama Robert H. Ennis. Menurut [12] critical thinking is a process, the goal of which is to make reasonable decisions about what to believe and what to do. Maksudnya, berpikir kritis merupakan sebuah proses yang bertujuan untuk membuat keputusan yang masuk akal mengenai apa yang dipercayai dan apa yang dilakukan.

Menurut [13], berpikir kritis kritis merupakan seni menganalisis dan mengevaluasi pikiran dengan pandangan lebih lanjut. Sedangkan [14], menjelaskan berpikir kritis sebagai sebuah proses yang terarah dan jelas yang digunakan dalam kegiatan mental seperti memecahkan masalah, mengambil keputusan, membujuk, menganalisis asumsi, dan melakukan penelitan ilmiah.

Menurut [12] terdapat enam unsur dasar dalam berpikir kritis yang disingkat menjadi FRISCO yaitu F (Focus), untuk membuat sebuah keputusan tentang apa yang diyakini maka harus bisa memperjelas pertanyaan atau isu tertentu. $\mathrm{R}$ (Reason), mengetahui alasan-alasan yang mendukung atau bertentangan dengan situasi dan fakta yang relevan. I (Inference), membuat kesimpulan yang beralasan atau menyuguhkan. Bagian penting dari langkah penyimpulan ini adalah mengidentifikasi asumsi dan mencari pemecahan, pertimbangan akan situasi dan bukti. S (Situation), memahami situasi dan selalu menjaga situasi dalam berpikir. C (Clarity), menjelaskan arti atau istilah-istilah yang digunakan. O (Overview), melangkah kembali dan meneliti secara menyeluruh keputusan yang diambil.

Keenam unsur dasar kemampuan berpikir kritis dijabarkan ke dalam enam indikator-indikator berpikir kritis yaitu penjelasan dasar, keputusan dasar, kesimpulan, penjelasan lebih lanjut, menalar dan pengintegrasian, dan terakhir adalah kemampuan tambahan. Keenam indikator kemampuan berpikir kritis ini diajabarkan lagi menjadi empat belas subindikator kemampuan berpikir kritis sebagai berikut. (1) Penjelasan dasar terdiri dari dua sub-indikator: memfokuskan pertanyaan dan menganalisis argumen. (2) Keputusan dasar terdiri dari tiga sub-indikator: mempertimbangkan kredibilitas sumber, mengobservasi dan mempertimbangkan laporan observasi, mendeduksi dan menilai hasil deduksi. (3) Kesimpulan terdiri dari dua sub-indikator: menginduksi dan mempertimbangkan induksi, membuat dan menilai hasil pertimbangan. (4) Penjelasan lebih lanjut terdiri dari dua sub-indikator: mendefinisikan istilah dan mempertimbangkan suatu definisi, mengidentifikasi asumsi-asumsi. Menalar dan pengintegrasian terdiri dari dua subindikator. Menalar, mengintegrasikan. Kemampuan tambahan terdiri dari tiga sub-indikator: melanjutkan dengan cara yang benar sesuai dengan situasi, sensitif, strategi retoris [15] dan [16].

Dalam penelitian ini, berpikir kritis adalah suatu proses kognisi siswa secara mendalam yang diterapkan dalam kegiatan pembelajaran yang memenuhi indikator-indikator sebagai berikut: memfokuskan pertanyaan, menganalisis argumen (mengidentifikasi alasan dan mengidentifikasi suatu ketidaktepatan), menginduksi dan mempertimbangkan hasil induksi, mengevaluasi, dan kemampuan memberikan alasan. 


\section{Hasil Belajar Fisika}

Hasil belajar dapat dijelaskan dengan memahami dua kata yang membentuknya, yaitu hasil dan belajar. Pengertian hasil mengarah pada suatu perolehan akibat dilakukannya suatu aktivitas atau proses yang mengakibatkan berubahnya input secara fungsional. Belajar dilakukan untuk mengusahakan adanya perubahan perilaku pada individu yang belajar. Perubahan perilaku itu merupakan perolehan yang menjadi hasil belajar [17].

Menurut [18] hasil belajar merupakan hasil dari suatu interaksi tindak belajar dan tindak mengajar. Sedangkan [19] mendefinisikan hasil belajar sebagai bentuk perubahan tingkah laku secara menyeluruh (komprehensif) yang terdiri atas unsur kognitif, afektif, dan psikomotorik secara terpadu pada diri siswa. Hasil belajar adalah perubahan perilaku secara keseluruhan bukan hanya salah satu aspek potensi kemanusiaan saja [20].

Hasil belajar fisika dalam penelitian ini hanya terbatas pada hasil belajar kognitif pada ranah $\mathrm{C1}$ sampai C6 (mengingat, memahami, mengaplikasi, menganalisis, mengevaluasi, dan mencipta) menggunakan taksonomi bloom edisi revisi [21]. Sehingga hasil belajar fisika dapat didefinisikan sebagai perubahan tingkah laku siswa pada ranah kognitif C1 sampai C6 (mengingat, memahami, mengaplikasikan, menganalisis, mengevaluasi, dan mencipta) setelah melakukan proses pembelajaran fisika melalui model pembelajaran inkuiri terstruktur dengan pendekatan saintifik.

\section{Metode Penelitian}

Penelitian ini merupakan penelitian quasi experiment dengan rancangan nonekuivalen atau untreated control group design with pretest and posttest.

Populasi penelitian ini adalah seluruh siswa kelas X SMAN 1 Gerung tahun pelajaran 2014/2015 sebanyak 6 kelas. Pengambilan sampel dilakukan dengan teknik clauter random sampling, sehingga terpilih kelas X-3 sebagai kelas eksperimen dan kelas $\mathrm{X}-6$ sebagai kelas kontrol.

Adapun variabel dalam penelitian ini terdiri dari satu variabel bebas dan dua variabel terikat. Variabel bebas dalam penelitian ini adalah model pembelajaran inkuiri terstruktur dengan pendekatan saintifik, sedangkan variabel terikatnya adalah kemampuan berpikir kritis dan hasil belajar fisika. Pada penelitian ini kelas eksperimen menggunakan model pembelajaran inkuiri terstruktur dengan pendekatan saintifik sedangkan kelas kontrol menggunakan model pembelajaran ekspositori.
Tes kemampuan berpikir kritis terdiri dari 6 butir soal dalam bentuk tes essay yang sudah divalidasi oleh ahli. Keenam soal ini meliputi indikatorindikator berpikir kritis yaitu: memfokuskan pertanyaan, mengidentifikasi alasan, mengidentifikasi suatu ketidaktepatan, menginduksi dan mempertimbangkan hasil induksi, mengevaluasi, dan kemampuan memberikan alasan. Adapun pedoman penskorannya menggunakan rubrik kemampuan berpikir kritis. Sedangkan untuk mengetahui tingkat pencapaian kemampuan berpikir kritis siswa dianalisis dengan persentase sebagai berikut.

$$
\text { Nilai }=\frac{\text { skor yang diperoleh }}{\text { skor maksimal }} \times 100
$$

Setelah diperoleh hasil persentase kemampuan berpikir kritis siswa, peneliti menentukan kategori kemampuan berpikir kritis siswa. Pemberian kategori bertujuan untuk mengetahui kualifikasi persentase kemampuan berpikir kritis siswa. Kemampuan berpikir kritis dibedakan menjadi 4 kategori menurut [22] sebagai berikut.

Tabel 1. Pedoman Kategori Berpikir Kritis

\begin{tabular}{cl}
\hline Skala Perolehan & \multicolumn{1}{c}{ Kategori } \\
\hline $81,25<x \leq 100$ & Sangat Kritis \\
$62,50<x \leq 81,25$ & Kritis \\
$43,75<x \leq 62,50$ & Kurang Ktitis \\
$25,00<x \leq 43,75$ & Sangat Kurang Kritis \\
\hline
\end{tabular}

Adapun tes hasil belajar fisika dari ranah kognitif C1 sampai C6 yang terdiri dari 30 butir soal pilihan ganda dan sudah diuji validitas, reliablilitas, taraf kesukaran dan daya beda soal, pada kelas kelas XI IPA 1 SMAN 1 Gerung sebanyak 50 butir soal.

Data yang diperoleh dari tes kemampuan berpikir kritis dan hasil belajar fisika siswa berupa data pretest yang bertujuan untuk melihat kemampuan awal dari kedua kelas dengan menggunakan uji homogenitas. Adapun data post-test bertujuan untuk melihat besar peningkatan setelah diterapkannya model pembelajaran inkuiri terstruktur dengan pendekatan saintifik. Analisis data post-test ini dilakukan uji normalitas, homogenitas dan hipotesis. Sebelum uji hipotesis dilakukan uji prasyarat yang meliputi uji normalitas menggunakan uji chi-square dan uji homogenitas menggunakan uji varians.

Penarikan kesimpulan untuk uji normalitas adalah jika $\chi_{\text {hitung }}^{2} \leq \chi_{\text {tabel}}^{2}$, maka data terdistribusi normal dan $\chi_{\text {hitung }}^{2}>\chi^{2}{ }_{\text {tabel }}$, maka data tidak terdistribusi normal dengan taraf signifikansi 5\%. Adapun untuk uji varians, jika Fhitung > Ftabel maka 
sampel tidak homogen dan jika Fhitung $\leq$ Ftabel maka sampel homogen. Apabila data sudah terdistribusi normal dan homogen, maka uji hipotesis dilanjutkan dengan statistik parametrik menggunakan t-test polled varians dengan derajat kebebasan $(\mathrm{dk})=$ n1 + n $2-2$ dan $\alpha=0,05$. Penarikan kesimpulan uji hipotesis adalah apabila $t_{\text {hitung }}>t_{\text {tabel }}$, maka $\mathrm{H}_{\mathrm{a}}$ diterima dan $\mathrm{H}_{\mathrm{o}}$ ditolak, dan apabila $\mathrm{t}_{\text {hitung }} \leq$ $\mathrm{t}_{\text {tabel}}$, maka maka $\mathrm{H}_{\mathrm{o}}$ diterima dan $\mathrm{H}_{\mathrm{a}}$ ditolak [23].

\section{HASIL DAN PEMBahasan}

\section{A. Hasil Penelitian}

Penelitian ini dilaksanakan dari bulan September 2014 sampai April 2015. Untuk melihat kemampuan awal siswa kelas eksperimen dan kelas kontrol dilakukan pre-test kemampuan berpikir kritis dan hasil belajar fisika pada materi suhu dan kalor. Setelah diberikan perlakuan pada kedua kelas, maka dilakukan post-test untuk melihat besar peningkatannya.

\section{Kemampuan Berpikir Kritis}

Rata-rata data pre-test kemampuan berpikir kritis siswa pada kelas eksperimen sebesar 36,36 dan kelas kontrol sebesar 29,06; untuk lebih jelasnya dapat dilihat pada tabel 2 berikut ini.

Tabel 2. Data Pre-test Kemampuan Berpikir Kritis Kedua Kelas

\begin{tabular}{ccc}
\hline & \multicolumn{2}{c}{ Pre-test Kemampuan Berpikir } \\
& Kritis \\
& Kelas & Kelas \\
Jumlah siswa & 33 & Kontrol \\
Rata-rata & 36,36 & 34 \\
Nilai tertinggi & 45,8 & 29,06 \\
Nilai terendah & 25 & 54,5 \\
\hline
\end{tabular}

Adapun analisis uji varians data pre-test hasil belajar fisika siswa menunjukkan $F_{\text {hitung }}$ sebesar 1,11 dan $F_{\text {tabel }}$ sebesar 1,81 dengan taraf signifikan 5\%. Hal ini menunjukkan $\mathrm{F}_{\text {hitung }}<\mathrm{F}_{\text {tabel }}$, maka data kedua kelas memiliki varians yang homogen, artinya kemampuan awal berpikir kritis siswa dari kedua kelas sama.

Data post-test kemampuan berpikir kritis siswa pada kelas eksperimen dan kelas kontrol setelah diberikan perlakuan dapat dilihat pada tabel 3 berikut ini.
Tabel 3. Data Post-test Kemampuan Berpikir Kritis Kelas Eksperimen dan Kelas Kontrol

\begin{tabular}{ccc}
\hline & $\begin{array}{c}\text { Kelas } \\
\text { Eksperimen }\end{array}$ & $\begin{array}{c}\text { Kelas } \\
\text { Kontrol }\end{array}$ \\
\hline Jumlah siswa & 33 & 34 \\
Rata-rata & 75,63 & 61,89 \\
Nilai tertinggi & 91,7 & 79,2 \\
Nilai terendah & 45,8 & 45,8 \\
\hline
\end{tabular}

Data post-test kemampuan berpikir kritis siswa menunjukkan bahwa rata-rata nilai pada kelas eksperimen sebesar 75,63 sedangkan pada kelas kontrol sebesar 61,89. Perbedaan nilai rata-rata kedua kelas yang begitu signifikan mengindikasikan bahwa model pembelajaran inkuiri terstruktur dengan pendekatan saintifik yang diterapkan pada kelas eksperimen memberikan hasil yang lebih baik dibandingkan dengan model pembelajaran ekspositori yang diterapkan pada kelas kontrol. Karena nilai ratarata ini hanya berlaku untuk kedua kelas dan tidak berlaku untuk populasi kelas $\mathrm{X}$, maka dilakukanlah uji hipotesis yang bertujuan untuk menggeneralisasikan data dan dapat berlaku untuk popuasi kelas X di SMAN 1 Gerung tahun pelajaran 2014/2015. Namun sebelum melakukan uji hipotesis dilakukanlah uji prasyarat analisis menggunakan uji normalitas dan homogenitas. Adapun hasil uji normalitas data post-test kemampuann berpikir kritis siswa pada kelas eksperimen dan kelas kontrol dapat ditunjukkan pada tabel 4 berikut ini.

Tabel 4. Hasil Perhitungan Normalitas Post-test Kemampuan Berpikir Kritis Siswa

\begin{tabular}{cccc}
\hline Kelas & $\chi^{2}$ hitung & $\chi^{2}$ tabel & $\begin{array}{c}\text { Hasil Uji } \\
\text { Normalitas }\end{array}$ \\
\hline Eksperimen & 8,15 & 11,070 & Normal \\
Kontrol & 3,98 & 11,070 & Normal \\
\hline$\alpha=5 \%$ & & &
\end{tabular}

$\alpha=5 \%$

Berdasarkan tabel 4, pada kelas eksperimen $\chi_{\text {hitung }}^{2}$ sebesar 8,15 dan $\chi_{\text {tabel }}^{2}$ sebesar 11,070; hal ini menunjukkan $\chi_{\text {hitung }}^{2}<\chi_{\text {tabel }}^{2}$, maka data terdistribusi normal. Sedangkan pada kelas kontrol $\chi^{2}$ hitung sebesar 3,98 dan $\chi_{\text {tabel }}^{2}$ sebesar 11,070; berarti $\chi_{\text {hitung }}^{2}<\chi_{\text {tabel }}^{2}$, maka data terdistribusi normal.

Uji prasyarat selanjutnya adalah uji homogenitas. Adapun hasil uji homogenitas yang dilakukan terhadap data post-test kemampuan berpikir kritis siswa pada kelas 
eksperimen dan kelas kontrol ditunjukkan pada tabel 5 berikut ini.

Tabel 5. Hasil Perhitungan Homogenitas Post-test Kemampuan Berpikir Kritis

\begin{tabular}{llll}
\hline \multicolumn{1}{c}{ Kelas } & $\mathrm{F}_{\text {hitung }}$ & $\mathrm{F}_{\text {tabel }}$ & $\begin{array}{c}\text { Hasil Uji } \\
\text { Homogenitas }\end{array}$ \\
\hline Eksperimen & 1,54 & 1,80 & Homogen \\
Kontrol & 1,54 & 1,80 & Homogen \\
\hline$\alpha=5 \%$ & & &
\end{tabular}

Berdasarkan tabel 5, diperoleh $\mathrm{F}_{\text {hitung }}$ sebesar 1,54 dan $F_{\text {tabel }}$ sebesar 1,80; berarti $\mathrm{F}_{\text {hitung }}<\mathrm{F}_{\text {tabel }}$, maka dapat disimpulkan bahwa data kedua kelas homogen.

Uji prasyarat analisis untuk uji hipotesis telah terpenuhi, dimana data kedua kelas normal dan homogen, maka dapat dilakukan uji hipotesis dengan statistik parametrik menggunakan t-test polled varians. Adapun hasil analisis t-test polled varians dapat ditunjukkan pada tabel 6 berikut ini.

Tabel 6. Hasil Analisis Uji Hipotesi Kemampuan Berpikir Kritis

\begin{tabular}{cccc}
\hline Kelas & $\mathrm{t}_{\text {hitung }}$ & $\mathrm{t}_{\text {tabel }}$ & Hasil Uji-t \\
\hline $\begin{array}{c}\text { Eksperimen } \\
\text { Kontrol }\end{array}$ & 5,78 & \multirow{2}{*}{1,9983} & $\begin{array}{l}\text { Ho ditolak, } \\
\text { Ha diterima }\end{array}$ \\
\hline$\alpha=5 \%$ & & &
\end{tabular}

Berdasarkan tabel 6, ditunjukkan bahwa $t_{\text {hitung }}$ sebesar 5,78 dan $t_{\text {tabel }}$ sebesar 1,9983; hal ini berarti $t_{\text {hitung }}>t_{\text {tabel }}$, maka dapat ditarik kesimpulan bahwa $\mathrm{H}_{0}$ ditolak dan $\mathrm{H}_{\mathrm{a}}$ diterima. Artinya, bahwa adanya pengaruh model pembelajaran inkuiri terstruktur dengan pendekatan saintifik terhadap kemampuan berpikir kritis siswa kelas X SMAN 1 Gerung tahun pelajaran 2014/2015.

\section{Hasil Belajar Fisika}

Rata-rata data pre-test hasil belajar fisika siswa pada kelas eksperimen sebesar 25,00 dan kelas kontrol sebesar 22,46. Data hasil pre-test lebih jelasnya dapat ditunjukkan pada tabel 7 .

Tabel 7. Data Pre-test Hasil Belajar Fisika Kelas Eksperimen dan Kelas Kontrol

\begin{tabular}{ccc}
\hline & $\begin{array}{c}\text { Pre-test } \text { Hasil Belajar Fisika } \\
\text { Kelas } \\
\text { Eksperimen }\end{array}$ & $\begin{array}{c}\text { Kelas } \\
\text { Kontrol }\end{array}$ \\
\hline Jumlah siswa & 33 & 34 \\
Rata-rata & 24,85 & 23,04 \\
Nilai tertinggi & 40 & 40 \\
Nilai terendah & 10 & 13,3 \\
\hline
\end{tabular}

Adapun analisis uji varians data pre-test hasil belajar fisika siswa kelas eksperimen dan kelas kontrol menunjukkan $\mathrm{F}_{\text {hitung }}$ sebesar 1,21 dan $F_{\text {tabel }}$ sebesar 1,80 dengan taraf signifikan $5 \%$, hal ini menunjukkan $\mathrm{F}_{\text {hitung }}<\mathrm{F}_{\text {tabel }}$, maka data kedua kelas memiliki varians yang homogen, artinya kemampuan awal dari kedua kelas sama.

Data post-test hasil belajar fisika siswa pada kelas eksperimen dan kelas kontrol setelah diberikan perlakuan dapat ditunjukkan pada tabel 8 berikut ini.

Tabel 8. Data Post-test Hasil Belajar Fisika Kelas Eksperimen dan Kelas Kontrol

\begin{tabular}{ccc}
\hline & $\begin{array}{c}\text { Kelas } \\
\text { Eksperimen }\end{array}$ & $\begin{array}{c}\text { Kelas } \\
\text { Kontrol }\end{array}$ \\
\hline Jumlah siswa & 33 & 34 \\
Rata-rata & 75,46 & 63,83 \\
Nilai tertinggi & 90 & 76,6 \\
Nilai terendah & 50 & 36,7 \\
\hline
\end{tabular}

Data post-test hasil belajar fisika siswa menunjukkan bahwa rata-rata nilai hasil belajar fisika siswa pada kelas eksperimen sebesar 75,46 sedangkan pada kelas kontrol sebesar 63,83 . Perbedaan nilai rata-rata kedua kelas yang begitu signifikan mengindikasikan bahwa model pembelajaran inkuiri terstruktur dengan pendekatan saintifik yang diterapkan pada kelas eksperimen memberikan hasil yang lebih baik dibandingkan dengan model pembelajaran ekspositori yang diterapkan pada kelas kontrol. Untuk bisa digeneralisasi dan dapat berlaku untuk popuasi kelas $\mathrm{X}$ SMAN 1 Gerung tahun pelajaran 2014/2015, maka dilakukan uji hipotesis. Sebelum uji hipotesis dilakukan uji normalitas dan homogenitas. Adapun hasil uji normalitas data post-test hasil belajar fisika siswa pada kedua kelas ditunjukkan pada tabel 9 berikut ini.

Tabel 9. Hasil Perhitungan Normalitas Post-test Hasil Belajar Fisika Siswa

\begin{tabular}{cccc}
\hline Kelas & $\chi^{2}{ }_{\text {hitung }}$ & $\chi^{2}{ }_{\text {tabel }}$ & Hasil Uji \\
& Normalitas \\
\hline Eksperimen & 3,697 & 11,070 & Normal \\
Kontrol & 8,22 & 11,070 & Normal \\
\hline$\alpha=5 \%$ & & &
\end{tabular}

Berdasarkan tabel 9, pada kelas eksperimen $\chi_{\text {hitung }}^{2}$ sebesar 3,697 dan $\chi_{\text {tabel }}^{2}$ sebesar 11,070; hal ini menunjukkan $\chi_{\text {hitung }}^{2}<\chi^{2}$ tabel, maka data terdistribusi normal. Sedangkan pada 
kelas kontrol $\chi^{2}$ hitung sebesar 8,22 dan $\chi_{\text {tabel }}^{2}$ sebesar 11,070; berarti $\chi^{2}{ }_{\text {hitung }}<\chi^{2}{ }_{\text {tabel }}$, maka data terdistribusi normal.

Uji prasyarat selanjutnya adalah uji homogenitas. Adapun hasil uji homogenitas yang dilakukan terhadap data post-test hasil belajar fisika siswa pada kelas eksperimen dan kelas kontrol ditunjukkan pada tabel 10 berikut ini.

Tabel 10. Hasil Perhitungan Homogenitas Post-test Hasil Belajar Fisika Siswa

\begin{tabular}{clll}
\hline Kelas & $\mathrm{F}_{\text {hitung }}$ & $\mathrm{F}_{\text {tabel }}$ & $\begin{array}{c}\text { Hasil Uji } \\
\text { Homogenitas }\end{array}$ \\
\hline $\begin{array}{c}\text { Eksperimen } \\
\text { Kontrol }\end{array}$ & 1,22 & 1,81 & Homogen \\
\hline$\alpha=5 \%$ & & &
\end{tabular}

Berdasarkan tabel 10, diperoleh $\mathrm{F}_{\text {hitung }}$ sebesar 1,22 dan $F_{\text {tabel }}$ sebesar 1,81; berarti $\mathrm{F}_{\text {hitung }}<\mathrm{F}_{\text {tabel }}$, maka dapat disimpulkan bahwa data kedua kelas homogen.

Uji prasyarat analisis untuk uji hipotesis telah terpenuhi, dimana data kedua kelas normal dan homogen, maka dapat dilakukan uji hipotesis dengan statistik parametrik menggunakan t-test polled varians. Adapun hasil analisis t-test polled varians dapat ditunjukkan pada tabel 11 berikut ini.

Tabel 11. Hasil Analisis Uji Hipotesi Hasil Belajar Fisika Siswa

\begin{tabular}{cccc}
\hline Kelas & $\mathrm{t}_{\text {hitung }}$ & $\mathrm{t}_{\text {tabel }}$ & Hasil Uji-t \\
\hline $\begin{array}{c}\text { Eksperimen } \\
\text { Kontrol }\end{array}$ & 4,39 & 1,998 & $\begin{array}{l}\text { Ho ditolak, } \\
\text { Ha diterima }\end{array}$ \\
\hline$\alpha=5 \%$ & & &
\end{tabular}

Berdasarkan tabel 11, ditunjukkan bahwa $t_{\text {hitung }}$ sebesar 4,39 dan $t_{\text {tabel }}$ sebesar 1,998; hal ini berarti $t_{\text {hitung }}>t_{\text {tabel }}$, maka dapat ditarik kesimpulan bahwa $\mathrm{H}_{0}$ ditolak dan $\mathrm{H}_{\mathrm{a}}$ diterima. Artinya, bahwa adanya pengaruh model pembelajaran inkuiri terstruktur dengan pendekatan saintifik terhadap hasil belajar fisika siswa.

\section{B. Pembahasan}

\section{Kemampuan Berpikir Kritis}

Penelitian ini bertujuan untuk mengetahui pengaruh model pembelajaran inkuiri terstruktur dengan pendekatan saintifik terhadap kemampuan berpikir kritis siswa kelas X SMAN 1 Gerung tahun pelajaran 2014/2015.
Hasil pengujian hipotesis terhadap data post-test kemampuan berpikir kritis siswa pada kelas eksperimen dan kelas kontrol dengan menggunakan uji-t menunjukkan bahwa adanya pengaruh model pembelajaran inkuiri terstruktur (MPIT) dengan pendekatan saintifik terhadap kemampuan berpikir kritis siswa. Selain itu dapat terlihat dari hasil post-test data kemampuan berpikir kritis siswa pada kedua kelas menunjukkan bahwa nilai rata-rata kelas eksperimen lebih tinggi dibandingkan dengan kelas kontrol. Hal ini menunjukkan MPIT dengan pendekatan saintifik lebih baik dibandingkan dengan model pembelajaran ekspositori. Berdasarkan penelitian yang telah dilakukan sebelumnya menunjukkan hal yang senada dengan hasil penelitian ini, seperti penelitian yang dilakukan oleh [24], [25], dan [26], menunjukkan bahwa model pembelajaran inkuiri dapat meningkatkan kemampuan berpikir kritis siswa. Selain itu, [27] menyatakan bahwa keterampilan berpikir kritis kelompok siswa yang mendapatkan model pembelajaran inkuiri lebih baik dibandingkan dengan siswa yang mendapakan model pembelajaran langsung.

MPIT dengan pendekatan santifik dapat melibatkan siswa secara optimal dalam proses pembelajaran sehingga siswa aktif mendapatkan pengetahuannya melalui serangkaian kegiatan inkuiri. Hal ini sesuai dengan apa yang dikemukakan oleh [28], pembelajaran yang menuntut siswa terlibat secara optimal dalam proses belajar dapat meningkatkan kemampuan berpikir kritis siswa. [27] juga menyatakan bahwa lingkungan belajar yang melibatkan siswa aktif dalam penyelidikan (penelitian) suatu informasi dan mengaplikasikan pengetahuan mereka dapat meningkatkan keterampilan berpikir kritis siswa.

Aspek-aspek kemampuan berpikir kritis yang harus dicapai siswa lebih banyak diaplikasikan dalam penerapan MPIT dengan pendekatan saintifik dibandingkan dengan model pembelajaran ekspositori. Dalam penerapan MPIT dengan pendekatan saintifik terdapat kegiatan pengamatan, membuat hipotesis, mengolah data, menganalisis data, membuat keputusan, membuat kesimpulan, berkomunikasi. Sedangkan model pembelajaran ekspositori terdapat kegiatan memperhatikan demonstrasi yang dilakukan oleh guru, kemudian menjawab LKS yang berkaitan dengan demonstrasi, dan kegiatan diskusi atau berkomunikasi. 
Berdasarkan rangkaian pembelajaran yang diterapkan pada kelas eksperimen menunjukkan adanya proses untuk melatih keterampilan berpikir kritis karena keterampilan berpikir kritis tidak akan berkembang apabila tidak dilatih. Seperti yang dikemukakan oleh [29], keterampilan berpikir kritis membutuhkan latihan, praktik, dan kesabaran. Keterampilan berpikir kritis tidak terjadi secara lahiriah, tetapi perlu dilatih dengan tujuan untuk menyiapkan siswa menjadi seorang pemikir kritis [28].

Kegiatan-kegiatan dalam model pembelajaran inkuiri terstruktur dengan pendekatan saintifik merupakan sarana yang lebih tepat dan efektif dalam pencapaian indikator-indikator kemampuan berpikir kritis, sehingga melalui MPIT dengan pendekatan saintifik ini dapat lebih mengembangkan kemampuan berpikir kritis siswa. Sesuai dengan penelitian [30] menyatakan bahwa model pembelajaran inkuiri dengan kegiatan ilmiah (pendekatan saintifik) dapat membantu siswa mengembangkan keterampilan berpikir kritis dan memungkinkan siswa untuk berpikir dan mengkonstruksi pengetahuannya seperti seorang saintis.

\section{Hasil Belajar Fisika Siswa}

Penelitian ini bertujuan untuk mengetahui pengaruh model pembelajaran inkuiri terstruktur (MPIT) dengan pendekatan saintifik terhadap hasil belajar fisika siswa kelas X SMAN 1 Gerung tahun pelajaran 2014/2015.

Hasil pengujian hipotesis terhadap data post-test hasil belajar fisika siswa pada kelas eksperimen dan kelas kontrol dengan menggunakan uji-t menunjukkan bahwa adanya pengaruh MPIT dengan pendekatan saintifik terhadap hasil belajar fisika siswa. Selain itu dapat terlihat dari hasil post-test data hasil belajar fisika siswa pada kedua kelas menunjukkan bahwa nilai rata-rata kelas eksperimen lebih tinggi dibandingkan dengan kelas kontrol. Hal ini menunjukkan bahwa MPIT dengan pendekatan saintifik yang diterapkan pada kelas ekseprimen lebih baik dibandingkan dengan model pembelajaran ekspositori yang diterapkan pada kelas kontrol.

MPIT dengan pendekatan saintifik sangat memposisikan siswa sebagai pusat dalam pembelajaran (student-centred), sehingga memberikan peluang pada peningkatan hasil belajar fisika. Sesuai dengan penelitian yang telah dilakukan oleh [31] dan [32] menunjukkan bahwa model pembelajaran inkuiri dapat meningkatkan hasil belajar. Model pembelajaran yang berorientasi pada inkuiri memberikan hasil belajar yang signifikan lebih besar dibandingkan dengan model konvensional [33]. Selain model pembelajaran inkuiri, pendekatan saintifik ternyata juga memberikan pengaruh terhadap hasil belajar. Penelitian yang yang telah dilakukan [34], [4], dan [11] menunjukkan bahwa bahwa pendekatan saintifk dapat meningkatkan hasil belajar siswa.

MPIT dengan pendekatan saintifik dapat memberikan peluang kepada siswa untuk berpartisipasi aktif dalam proses belajar. Siswa yang belajar untuk menemukan konsep pengetahuannya sendiri akan memperoleh pengalaman lebih bermakna dan pengetahuannya lebih kuat melekat dalam ingatan mereka. Dengan kuatnya informasi yang melekat pada memori siswa, tentu akan berdampak pula terhadap perolehan hasil belajar siswa. Sebaliknya pembelajaran ekspositori lebih menekankan kepada proses penyampaian materi secara verbal dari seorang guru kepada siswa agar siswa dapat menguasai materi pembelajaran secara optimal. Dalam penerapan model pembelajaran ekspositori pada kelas kontrol, siswa dijadikan sebagai penerima yang pasif dan hanya menghafal tanpa belajar untuk berpikir. Sehingga pengajaran bukanlah untuk menanamkan konsep tetapi lebih mengarah pada hafalan.

Pada penelitian ini penerapan MPIT dengan pendekatan saintifik sangat memposisikan siswa sebagai pusat dalam pembelajaran (studentcentred), sehingga memberikan peluang pada peningkatan hasil belajar. Sesuai dengan hasil penelitian yang telah dilakukann oleh [35] menyatakan bahwa MPIT dapat meningkatkan prestasi jangka panjang. Menurut [36] MPIT dapat meningkatkan pemahaman siswa. Dengan meningkatnya pemahaman, maka berdampak pada hasil belajar yang tinggi pula. Menurut [5] dan [6] MPIT memberikan hasil belajar yang lebih tinggi dibandingkan dengan model pembelajaran konvensional.

Hasil penelitian ini juga senada dengan penelitian [37] menyatakan terdapat perbedaan yang signifikan antara model pembelajaran saintifik inkuiri dan pembelajaran konvensional terhadap hasil belajar siswa. [38] Menyatakan model pembelajaran saintifik inkuiri dapat meningkatkan hasil belajar siswa. 
MPIT dengan pendekatan saintifik memiliki beberapa kelebihan dibandingkan dengan model pembelajaran ekspositori, diantaranya adalah siswa yang belajar melalui MPIT dengan pendekatan saintifik memiliki motivasi belajar yang lebih tinggi dibandingkan dengan siswa yang mengikuti pembelajaran ekspositori. Hal ini karena proses MPIT dengan pendekatan saintifik melatih siswa untuk aktif dalam proses pembelajaran dan siswa merasa senang ketika dilibatkan langsung dengan belajar, sedangkan siswa yang belajar dengan model pembelajaran ekspositori memiliki motivasi belajar yang rendah karena guru memposisiskan siswa sebagai penerima (siswa pasif) materi pelajaran dan proses pembelajaran dalam bentuk verbal. Selain itu MPIT dengan pendekatan saintifik dapat meningkatkan pemahaman siswa, karena pemahaman yang didapatkan melalui serangkaian proses belajar. Hal ini berdampak pada hasil belajar pada kelas eksperimen lebih baik dibandingkan dengan kelas kontrol.

\section{PENUTUP}

Berdasarkan hasil penelitian dan pembahasan maka dapat disimpulkan bahwa terdapat pengaruh model pembelajaran inkuiri terstruktur dengan pendekatan saintifik terhadap kemampuan berpikir kritis dan hasil belajar fisika siswa kelas X SMAN 1 Gerung tahun pelajaran 2014/2015. Model pembelajaran inkuiri terstruktur dengan pendekatan saintifik lebih baik dibandingkan dengan model pembelajaran ekspositori. Diharapkan dapat dilakukan penelitian lebih lanjut dengan mengukur kemampuan berpikir kritis lainnya.

\section{UCAPAN TERIMA KASIH}

Terima kasih penulis ucapkan untuk bapak $\mathrm{H}$. Nasrun S.Pd., MM selaku kepala SMAN 1 Gerung serta bapak Saryono, S.Pd selaku guru kelas, seluruh siswa kelas X-3 dan X-6 tahun pelajaran 2014/2015 yang telah berpartifipasi dan kerjasama dalam penelitian ini, serta seluruh pihak yang telah membantu penelitian ini.

\section{REFERENSI}

[1] UNDP. 2010. Human Development Report 2010: 20th Anniversary Edition. New York: Palgrave Macmillan.

[2] Hikmawati dan Gunada, I.W. 2013. Buku Ajar Kajian Fisika SMA. Mataram: FKIP Press.

[3] Banci, H. and Bell, R. 2008. The Many Levels Of Inquiry. Science and Children: 26-28.
[4] Marjan, J., Arnyana, I.B., dan Setiawan, I.G.A. 2014. Pengaruh Pembelajaran Pendekatan Saintifik Terhadap Hasil Belajar Biologi dan Keterampilan Proses Sains Siswa MA Mu'allimat NW Pancor Selong Kabupaten Lombok Timur Nusa Tenggara Barat. e-Journal Program Pascasarjana Universitas Pendidikan Ganesha Program Studi IPA. Vol. 4 Tahun 2014.

[5] Hafsyah, S.N., Prihandono, T., dan Yushardi. 2012. Penerapan Model Inkuiri Terstruktur dengan Media Virtual-LAB pada Pembelajaran Fisika Di SMP. Jurnal Pembelajaran Fisika (JPF). Vol. 1, No. 2 September 2012.

[6] Mutiah, A. 2014. Pengaruh Pembelajaran Inkuiri Terstruktur (Structured Inquiry) terhadap Hasil Belajar Siswa Pada Benda dan Sifatnya. Jurnal Pendidikan Dasar. Vol.1, No.1, April 2014.

[7] NRC. 2000. Inquiry and The National Science Education Standars: A Guide For Teaching and Learning. Washington D.C.: National Academy Press.

[8] Alberta. 2004. Focus On Inquiry: A Teacher's Guided to Implementing Inquiry-Based Learning. Canada: Alberta Learning.

[9] Colburn, A. 2000. An Inquiry Primer. Science Scope: $42-44$.

[10] Amri, S., dan Ahmadi, I.K. 2010. Proses Pembelajaran Kreatif dan Inovatif dalam Kelas. Jakarta: PT. Prestasi Pustakaraya.

[11] Machin, A. 2014. Implementasi Pendekatan Saintifik, Penanaman Karakter dan Konservasi Pada Pembelajaran Materi Pertumbuhan. Jurnal Pendidikan IPA Indonesia. Vol. 3, No. 1 April 2014.

[12] Ennis, R.H. 1996. Critical Thinking. USA: Prentice-Hall, Inc.

[13] Paul, R. and Elder, L. 2008. The Miniature Guide to Critical Thinking: Concepts and Tools. $28^{\text {th }}$ Annual International Conference On Critical Thinking. California.

[14] Johnson, E.B. 2008. Contextual Teaching and Lerning: Menjadikan Kegiatan BelajarMengajar Mengasyikkan dan Bermakna. Diterjemahkan oleh Ibnu Setiawan. Bandung: Penerbit MLC.

[15] Ennis, R.H. 1998. Is Critical Thinking Culturally Biased? Teaching Philosophy, 21,1 (March), 1533.

[16] Ennis, R.H. 2011. The Nature of Critical Thinking: An Outline of Critical Thinking Dispositions and Abilities. The Sixth 
International Conference on Thinking at MIT. Cambridge.

[17] Purwanto. 2013. Evaluasi Hasil Belajar. Yogyakarta: Pustaka Pelajar.

[18] Dimyati dan Mudjiono. 2013. Belajar dan Pembelajaran. Jakarta: Rineka Cipta.

[19] Sudjana, N. 2013. Dasar-Dasar Proses Belajar Mengajar. Bandung: Sinar Baru Algensindo.

[20] Suprijono, A. 2013. Cooperative Learrning. Yogyakarta: Pustaka Pelajar.

[21] Anderson, L. W. dan Krathwohl, D.R. 2010. Kerangka Landasan Untuk Pembelajaran, Pengajaran, dan Asesmen: Revisi Taksonomi Pendidikan Bloom. Diterjemahkan oleh Agung Prihantoro. Yogyakarta: Pustaka Pelajar.

[22] Yuliati, D.I., Yulianti, D., dan Khanafiyah, S. 2011. Pembelajaran Fisika Berbasis Hands On Activities Untuk Menumbuhkan Kemampuan Berpikir Kritis dan Meningkatkan Hasil Belajar Siswa SMP. Jurnal Pendidikan Fisika Indonesia. Vol.7 Januari 2011: 23-27.

[23] Sugiyono. 2014. Metode Penelitian Pendidikan: Pendekatan Kuantitatif, Kualitatif, dan $R \& D$. Bandung: Alfabeta.

[24] Anggareni, N.W., Ristiati, N.P., dan Widiyanti, N.L.P.M. 2013. Implementasi Strategi Pembelajaran Inkuiri Terhadap Kemampuan Berpikir Kritis dan Pemahaman Konsep IPA Siswa SMP. E-Journal Pascasarjana Universitas Pendidikan Ganesha Program Studi IPA. Vol. 3 Tahun 2013.

[25] Avesec, S., and Kocijancic, S. 2014. The Effect of Use of an Inquiry-Based Approach in an Open Learning Middle School Hydraulic Turbine Optimisation Course. WIETE. Vol.12, No.3, 2014.

[26] Umami, R. dan Jatmiko, B. 2013. Penerapan Model Pembelajaran Inkuiri dengan Pendekatan SETS (Science, Environment, Technology and Society) Pada Poko Bahasan Fluida Statis Untuk Meningkatkan Keterampilan Berpikir Kritis Siswa Kelas XI SMA Negeri 1 Gedangan. Jurnal Inovasi Pendidikan Fisika. Vol. 02 No.03 Tahun 2013: 61-69.

[27] Sutama, I.N., Arnyana, I.B.P., dan Swasta, I.B.J. 2014. Pengaruh Model Pembelajaran Inkuiri Terhadap Keterampilan Berpikir Kritis dan Kinerja Ilmiah Pada Pelajaran Biologi Kelas XI IPA SMA Negeri 2 Amplapura. E-Journal Program Pascasarjana Universitas Pendidikan Ganesha program Studi IPA. Vol. 4 Tahun 2014.
[28] Rahma, A.N. 2013. Pengembangan Perangkat Pembelajaran Model Inkuiri Berpendekatan SETS Materi Kelarutan dan Hasil Kali Kelarutan untuk menumbuhkan Keterampilan Berpikir Kritis dan Empati Siswa Terhadap Lingkungan. Journal of Education Research and Evaluation. Vol.1 No. 2. Tahun 2012: 133-138.

[29] Snyder, L.G. and Snyder, M.J. 2008. Teaching Critical Thinking and Problem Solving Skills. The Delta Pi Epsilon Journal. Vol.L, No. 2, Spring/Summer, 2008: 90-99.

[30] Corlu, M.A., and Corlu, M.S. 2012. Scientific Inquiry Based Professional Development Models In Teacher Education. Education Sciences Theory \& Practice. Vol.1 Desember. Winter: 514-521.

[31] Roswati. 2014. Penerapan Model Pembelajaran Inkuiri Untuk Meningkatkan Hasil Belajar Fisika Siswa Kelas VIII SMP Negeri 2 Tanjung Pura Tahun Pelajaran 2013/2014. Jurnal Pendidika Fisika. Vol.3 No.1 Juni 2014.

[32] Kristianingsih, D.D., Sukiswo, S.E., dan Khanafiyah,S. 2010. Peningkatan Hasil Belajar Siswa Melalui Model Pembelajaran Inkuiri Dengan Metode Pictorial Riddle Pada Pokok Bahasan Alat-Alat Optik di SMP. Jurnal Pendidikan Fisika Indonesia. Vol. 6. Januari 2010: 10-13.

[33] Mao, S.L. and Chang, C.Y. 1998. Impacts of an Inquiry Teaching Method on Earth Science Student's Learning Outcomes And Attitudes At The Secondary School Level. Proc. Natl.Sci. Counc. Roc.(D). Vol. 8, No.3, pp.93-101.

[34] Hidayati, N. 2014. Pengaruh Penggunaan Pendekatan Ilmiah (Scientific Approach) Dalam Pembelajaran Terhadap Hasil Belajar Siswa Kelas XII TITL 1 SMK Negeri 7 Surabaya Pada standar Kompetensi Mengoprasikan Sistem Kendali Elektromagnetik. Jurnal Pendidikan Teknik Elektro. Vol. 03 No. 02 Tahun 2014: 2529.

[35] Schmid, S., and Bogner, F.X. 2015. Effect of Students's Effort Scores in a Structured Inquiry Unit on Long-Term Recall Abilities of Content Knowledge. Education Researh International. Handawi Publishing Corporation. Vol. 2015, article ID 826734.

[36] Salim, K., and Tiawa, D.H. 2015. Implementation of Structured Inquiry Based Model Learning Toward Students' Understanding of Geometry. International 
Journal of Research in Eduction and Science (IJRES). Vol.1, Issue 1, Winter 2015.

[37] Hussain, D.A., Azzem, M., and Shakoor, A. 2011. Physics Teaching Methods: Scientific Inquiry $\mathrm{Vs}$ Traditional Lecture. International Journal of Humanities and Social Science. Vo.1. No.19 Desember 2011.

[38] Sihotang, D.C.N. 2014. Analisis Model Pembelajaran Scientific Inquiry dan Sikap Ilmiah Terhadap Hasil Belajar Siswa Pada Pembelajaran Fisika. Jurnal Pendidika Fisika. Vol.3 No.2 Desember 2014.

\section{Biografi Penulis}

Lia Saptini Handriani, S.Pd, lahir di Suradadi, 16 Januari 1993. Tahun 2005 lulus di SDN 1 Suradadi, Lombok Timur, tahun 2008 lulus dari SMPN 1 Terara Lombok Timur. Tahun 2011 lulus dari SMAN 1 Terara Lomok Timur dan melanjutkan pendidikan S-1 di Universitas Mataram pada Program Studi Pendidikan Fisika hingga meraih gelar sarjana tahun 2015. 